\title{
Burkitt's lymphoma of the duodenum in a patient with AIDS
}

\author{
Linfoma de Burkitt do duodeno em um paciente com AIDS
}

\author{
Marcelo Corti ${ }^{1}$, María Florencia Villafañe ${ }^{1}$, Liliana Souto ${ }^{1}$, Ricardo Schtirbu ${ }^{1}$, \\ Marina Narbaitz ${ }^{2}$ and Marcela de Dios Soler ${ }^{2}$
}

\begin{abstract}
Non-Hodgkin's lymphoma of B-cell type is the second most common neoplasm after Kaposi's sarcoma, among patients with human immunodeficiency virus infection. Most non-Hodgkin's lymphoma cases that are associated with acquired immunodeficiency syndrome involve extranodal sites, especially the digestive tract and the central nervous system. We report a case of primary lymphoma of the duodenum in a patient with AIDS. Upper gastrointestinal endoscopy revealed pseudopolypoid masses found in the second portion of the duodenum. A complete diagnostic study including histological, immunohistochemical and virological analyses showed high-grade B-cell Burkitt's lymphoma. The Epstein-Barr virus genome was detected in biopsies by immunobistochemical and in situ hybridization.
\end{abstract}

Key-words: Non-Hodgkin's lymphoma. Duodenum. AIDS. Epstein-Barr virus.

\section{RESUMO}

O linfoma não-Hodgkin de células B é a segunda neoplasia mais comum em pacientes com infecção pelo vírus da imunodeficiência bumana depois do sarcoma de Kaposi. A maioria dos casos de linfoma não-Hodgkin associados com a síndrome da imunodeficiência adquirida envolve locais extraganglionares, especialmente o trato digestivo e o sistema nervoso central. Nós relatamos um caso de linfoma primário do duodeno em um paciente com AIDS. Uma endoscopia digestiva alta mostrou massas pseudopolipóides encontradas na segunda porção do duodeno. Um estudo diagnóstico completo incluindo exames histológicos, imunobistoquímicos e virológicos mostrou um linfoma de células B tipo Burkitt. Detectou-se genoma do vírus Epstein-Barr em biópsias por hibridização in situ e imuno-histoquímica.

Palavras-chaves: Linfoma não-Hodgkin. Duodeno. AIDS. Virus de Epstein-Barr.

Non-Hodgkin's lymphomas (NHL) are the second most frequent malignancies in acquired immunodeficiency syndrome (AIDS) patients. More than $90 \%$ of HIV-associated NHL is derived from B cells and the majority is high-grade and extranodal. The digestive tract is one of the most common extranodal primary sites for NHL in AIDS patients, accounting for $40 \%$ of all primary extranodal lymphomas ${ }^{11}$. Burkitt's lymphoma (BL) has frequently been reported as a neoplasm in HIV-infected patients. These lymphomas are now better designated as AIDS-related $\mathrm{BL}^{1}$.

We report a case of primary BL of the duodenum in an AIDS patient.

\section{CASE REPORT}

A 45-year-old man infected with the human immunodeficiency virus (HIV) and hepatitis $\mathrm{C}$ virus (HCV) was admitted to our unit for AIDS-related illness with fever $\left(38^{\circ} \mathrm{C}-38.5^{\circ} \mathrm{C}\right)$, anorexia, upper abdominal pain, night sweats and weight loss of three months duration. He had no history of AIDS-defining illness and he had never received highly active antiretroviral therapy (HAART). Physical examination revealed that he had lost approximately $15 \mathrm{~kg}$ of weight during the last three months prior to admission. Lung and cardiac auscultation were normal. His abdomen was tender, with spontaneous epigastric and right hypochondrium pain that increased during palpation and hepatomegaly $(2 \mathrm{~cm}$ below the right costal margin). He did not present rebound tenderness.

The relevant laboratory findings were: hemoglobin $10.2 \mathrm{~g} / \mathrm{dl}$; hematocrit $36 \%$; leukocytes $5,600 / \mathrm{mm}^{3}$; platelets $156,000 / \mathrm{mm}^{3}$; lactate dehydrogenase 1,585U// and alkaline phosphatase 2,445U/. Liver function, transaminase level, kidney function and coagulation tests were normal. The CD4 T cell count was $87 \mathrm{cell} / \mathrm{ul}$ and the plasma viral load was 86,120 copies/ml $\left(\log _{10} 4.8\right)$. Multiple blood, urine and sputum cultures were all negative.

A chest X-ray was normal. Abdominal ultrasound showed hepatomegaly with increased echogenicity, isoechoic periportal

\footnotetext{
1. Division of HIV/AIDS disease, F. J. Muñiz Infectious Diseases Hospital, Buenos Aires, Argentina. 2. Histopathological Laboratory, National Academy of Medicine, Buenos Aires, Argentina.

Address to: Dr. Marcelo Corti. HIV/AIDS Division. Puán $3812^{\circ} \mathrm{C} 1406 \mathrm{CQG}$, Buenos Aires, Argentina.

Tel: $54114432-3762$

e-mail: marcelocorti@fibertel.com.ar

Recebido em 26/4/2006

Aceito em 2/5/2007
} 
adenopathy and splenomegaly. Abdominal computed tomography (CT) scan showed the same signs as the ultrasonography. CT scan of the thorax and pelvis were normal. A bone marrow biopsy did not show atypical cells.

Upper digestive tract endoscopy was performed; the esophagus and stomach were normal, and inspection of the second portion of the duodenum revealed pseudopolypoid masses (Figure 1). Several samples for biopsy and microbiological cultures were taken. Histopathological examination of the duodenal biopsies showed a dense and diffuse infiltrate of lymphoid cells with large and multinucleated cells with prominent inclusion-like nucleoli. The atypical cells showed hyperchromatic central nuclei and one to three nucleoli near the basal membrane (Figures 2 and 3). Immunostaining was performed on paraffin-embedded tissue by means of the avidin-biotin complex technique. Monoclonal antibodies demonstrated that the atypical cells showed reactivity to anti-CD20 (PAN B) and CD10; the T-cell marker CD3 was negative. All neoplastic cells showed intense staining with the Ki 67 antigen, consistent with a very high proliferation index (close to $100 \%$ ). The histopathological findings were consistent with

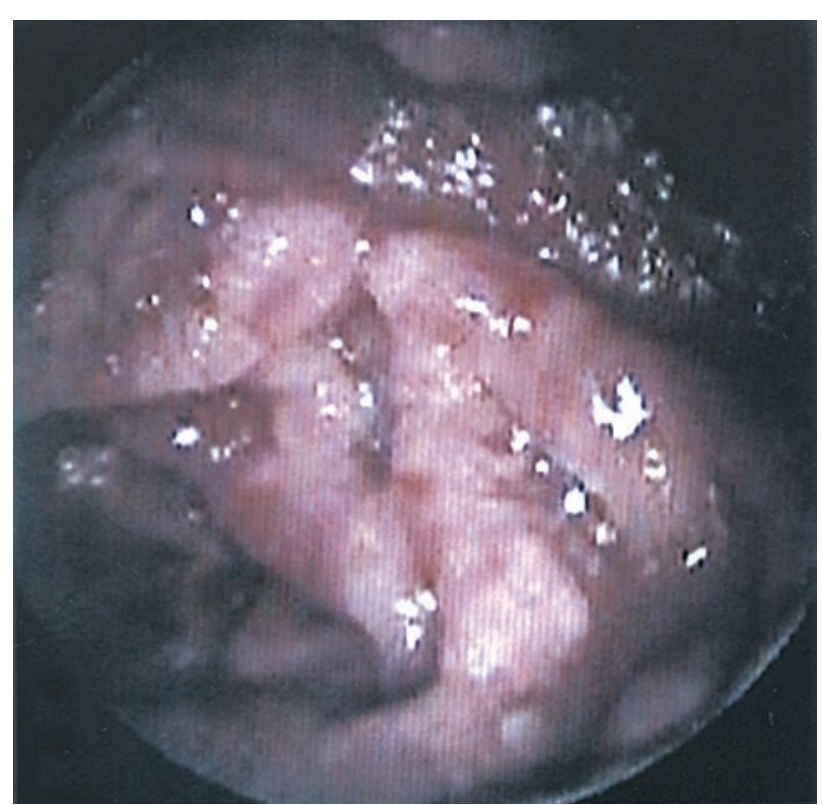

Figure 1 - Upper gastrointestinal endoscopy showing pseudopolypoid masses in the second portion of the duodenum.

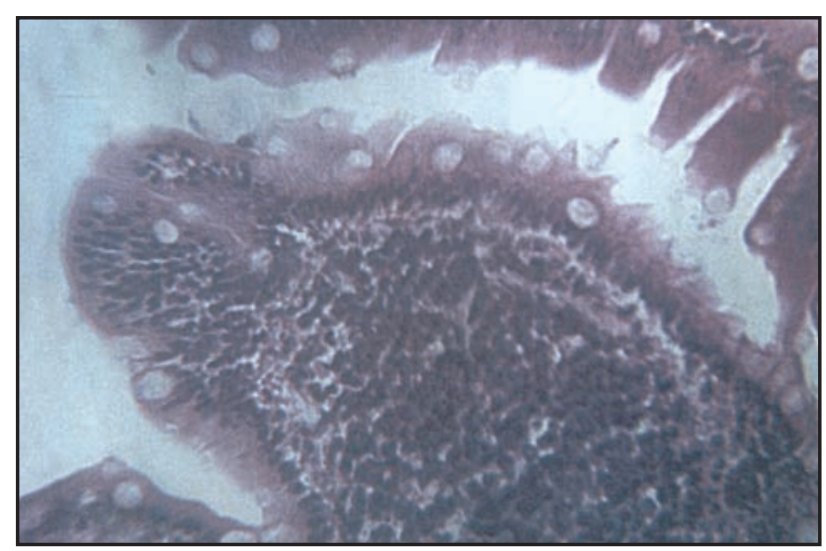

Figure 2 - Dense and atypical lymphoid infiltrate of the glands and stroma of the duodenum.

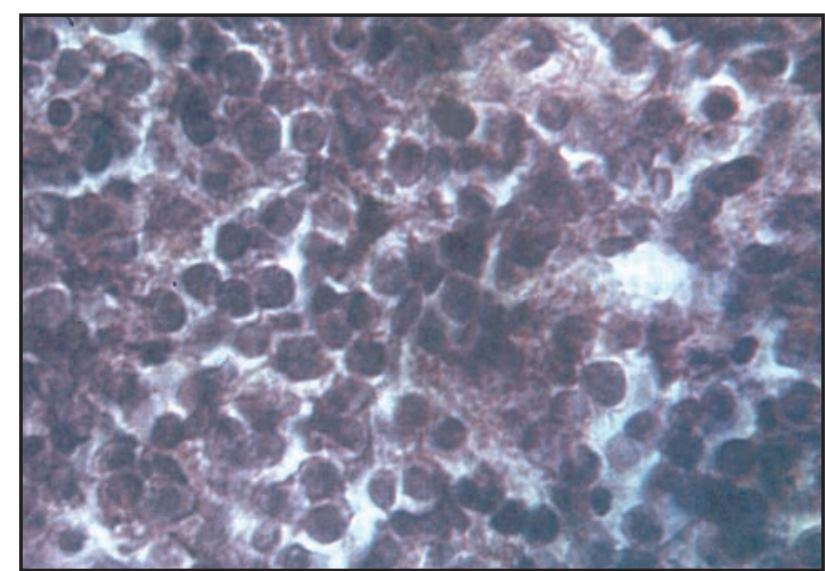

Figure 3 - Lymphoid infiltrate with large and multinucleated cells and prominent inclusions-like nucleoli.

the diagnosis of BL. Epstein-Barr virus (EBV) in association with latent membrane protein-1 (LMP-1) was detected in tumor cells by immunohistochemical techniques, and EBV-encoded mRNA was also detected by in situ hybridization.

The patient died due to progressive disease one month after admission. His physical condition did not allow him to receive either chemotherapy or antiretroviral therapy.

\section{DISCUSSION}

The lymphomas associated with HIV include high-grade Bcell lymphomas (the vast majority), BL, two subtypes of diffuse large B-cell lymphoma (centroblastic and immunoblastic) and, finally, two uncommon lymphomas that occur specifically in HIV-positive patients, called primary effusion lymphoma (PEL) and plasmablastic lymphoma of the oral cavity. There are two types of BL. The African or endemic type, which is frequent in children, presents with a jaw or retroperitoneal mass and is strongly associated with Epstein-Barr virus infection ${ }^{13}$. The other type, sporadic BL, especially affects the adult HIV-positive population, with identical histology but typically presenting as an intra-abdominal mass or intraluminal digestive tract lesion ${ }^{13}$, as could be seen in our patient.

The estimated relative risk of NHL-associated HIV infection is 100 times greater than in the general population and this risk increases with the progressive immunosuppression related to the retrovirus $^{15}$. The association with the $\mathrm{CD} 4 \mathrm{~T}$ cell count is higher for NHL than for Kaposi's sarcoma. Our patient presented a diagnosis of advanced HIV/AIDS disease with severe immunodepression and CD4 T cell count lower than $100 \mathrm{cell} / \mathrm{\mu l} \mathrm{l}^{15}$.

One of the major clinical characteristics of AIDS-associated NHL is the high frequency of extranodal involvement, including the gastrointestinal tract at initial presentation, as in our patient. The relationship between NHL and the digestive tract has been well established in the medical literature. The gastrointestinal tract is the second most common extranodal primary site of NHL in AIDS patients after the central nervous system. The stomach, distal ileum and cecum are the most commonly involved sites ${ }^{8}$. BL of the 
duodenum is rare and affects $20 \%$ to $30 \%$ of the patients. Most of the tumors are found in the second portion of the duodenum, like in our patient. In a series of 45 consecutive necropsies on adults patients with AIDS, de Carvalho et $\mathrm{al}^{3}$ encountered only seven (15.5\%) neoplasias and only one gastric lymphoma.

In AIDS patients, the clinical presentation and histopathological findings are consistent, in most cases, with primary neoplasms of the digestive tract ${ }^{8}$. Patients usually present with mild and nonspecific gastrointestinal symptoms and "B" symptoms such as weight loss, unexplained fever and night sweats ${ }^{2}$. These symptoms are identical to those of numerous opportunistic infections and may delay the diagnosis of lymphoma. Consequently, a high suspicion rate is necessary when infectologists evaluate patients with HIV/ AIDS and chronic abdominal symptoms. In 11 consecutive AIDS patients with gastrointestinal lymphomas, Cappell et $\mathrm{al}^{2}$ determined the frequencies of significant gastrointestinal complications such as bleeding and intestinal obstruction.

Early endoscopy followed by histopathological examination of biopsy smears helps to identify lymphomas of the digestive tract in AIDS patients.

Epstein-Barr virus is strongly associated with the pathogenesis of NHL in AIDS patients. Epstein-Barr virus genome is present in $25 \%$ to $40 \%$ of $\mathrm{HIV}$-associated $\mathrm{BL}^{5}{ }^{10}$. The presence of Epstein-Barr genome in atypical cells can be demonstrated by two techniques: immunohistochemistry and in situ hybridization ${ }^{49}$.

The Medline, Embase and Cochrane databases were searched to identify articles on duodenal BL associated with AIDS. The search was performed using the following key words: Burkitt lymphoma, duodenum, HIV and AIDS. To our knowledge, BL of the duodenum in a patient with AIDS has not been previously reported in the medical literature.

With improved survival among AIDS patients, there may be an increased in AIDS-related malignancies ${ }^{72}{ }^{14}$. The significant improvement in the survival of patients with HIV-NHL is associated with the positive impact of highly active antiretroviral therapy (HAART) on the survival of these patients with centroblastic and immunoblastic NHL. However, the prognosis for AIDS-associated BL remains poor, despite the use of HAART' ${ }^{6}$.

\section{REFERENCES}

1. Bellan C, Lazzi S, De Falco G, Nyongo A, Giordano A, Leoncini L. Burkitt's lymphoma: new insights into molecular pathogenesis. Journal of Clinical Pathology 56:188-193, 2003.

2. Cappell MS, Botros N. Predominantly gastrointestinal symptoms and signs in 11 consecutive AIDS patients with gastrointestinal lymphoma: a multicenter, multiyear study including 763 HIV-seropositive patients. American Journal of Gastroenterology 89:545-549, 1994.

3. Carvalho MG, Rodrigues MA, Marques ME, Franco M, Montenegro MR. Lesions of the gastrointestinal tract in acquired immunodeficiency syndrome: study of 45 consecutive necropsies. Revista da Sociedade Brasileira de Medicina Tropical 27: 135-141, 1994.

4. Corti M, Villafañe F, Trione N, Schtirbu R, Yampolsky C, Narbaitz M. Linfomas primarios del sistema nervioso central en pacientes con sida. Enfermedades Infecciosas y Microbiología Clinica 22:332-336, 2004.

5. Gandhi MK, Khanna R. Viruses and lymphoma. Pathology 37:420-433, 2005.

6. Gerard L, Galicier L, Maillard A, Boulanger E, Quint L, Matheron S, Cardon B, Meignin $\mathrm{V}$, Oksenhendler E. Systemic non-Hodgkin lymphoma in HIV-infected patients with effective suppresion of HIV replication: persistence recurrence but improved survival. Journal of Acquired Immune Deficiency Syndrome 30:478-484, 2002.

7. Grulich AE, Vajdic CM. The epidemiology of non-Hodgkin lymphoma. Pathology 37:409-419, 2005.

8. Gurney KA, Cartwright RA, Gilman EA. Descriptive epidemiology of gastrointestinal non-Hodgkin's lymphoma in a population based registry. British Journal of Cancer 79:1929-1934, 1999.

9. Hamilton-Dutoit SJ, Pallesen G, Karkov J, Skinjoy P, Franzmann MB, Pedersen C Identification of EBV-DNA in tumor cells of AIDS-related lymphomas by in-situ hybridization. The Lancet 1:554-555, 1989.

10. Hamilton-Dutoit SJ, Raphael M, Audouin J, Diebold J, LisseI, Pedersen C, Oksenhendler E, Marelle L, Pallesen G. In situ demonstration of Epstein-Barr virus small RNAs (EBER 1) in acquired immunodeficiency syndrome-related lymphomas: correlation with tumor morphology and primary site. Blood 82:619-624, 1993.

11. Ioachim HL, Dorsett HB, Cronin W, Maya M, Wahl S. Acquired immunodeficiency syndrome associated lymphomas: clinic, pathologic, immunologic and viral characteristics of 11 cases. Human Pathology 7:659-673, 1991.

12. Navarro JT, Ribera JM, Oriol A, Tural C, Millá F, Feliú E. Improved outcome of AIDSrelated lymphoma in patients with virologic response to highly active antiretroviral therapy. Journal of Acquired Immune Deficiency Syndrome 32:347-348, 2003.

13. Onder AM, Reeves-Garica J. The endoscopic and computed tomographic appearance of Burkitt's lymphoma of the stomach with follow-up studies. International Pediatrics 18:55-57, 2003.

14. Ribera JM, Navarro JT. Linfomas en pacientes con infección por el VIH. Las cosas han cambiado para bien. Enfermedades Infecciosas y Microbiología Clinica 22:313-314, 2004

15. Weisenburger DD. Epidemiology of non-Hodgkin's lymphoma. Recent findings regarding an emerging epidemic. Annals of Oncology S19-S24, 1994. 